\title{
Anthocyanins from blackberry (Rubus fructicosus L.) impregnated in yam bean (Pachyrhizus erosus (L.) Urb.) by osmotic dehydration
}

\author{
Alicia GRAJALES-LAGUNES ${ }^{1}$ (D), Luis CABRERA-RUIZ², Federico GUTIÉRREZ-MICELI ${ }^{2}$ (D), \\ Miguel Angel RUIZ-CABRERA ${ }^{1}$, Luc DENDOOVEN ${ }^{3}$ (D), Miguel ABUD-ARCHILA ${ }^{2 *}$ (D)
}

\begin{abstract}
Yam bean (Pachyrhizus erosus (L.) Urb.) tuber has a low carbohydrate content and contains several aminoacids, but contains few active compounds, such as vitamins and antioxidants. Anthocyanins are antioxidants found in Rubus fructicosus L. The osmotic drying is a technique that can be used to impregnate antioxidants in a matrix, so the objective of this study was to impregnate yam bean tuber slices with anthocyanin. The effect of temperature $\left(40,50\right.$ and $\left.60^{\circ} \mathrm{C}\right)$, sucrose content $\left(40,50\right.$ and $\left.60^{\circ} \mathrm{Brix}\right)$ and vacuum pulse $(0,300$ and 600 mbar) on water loss $(W L)$, solid gain $(S G)$, color changes $(\Delta \mathrm{E})$ and anthocyanin concentration $(\triangle \mathrm{A})$ during osmotic drying of yam bean slices was determined. Polynomial equations were used to determine changes in $W L$, $S G, \Delta \mathrm{E}$ and $\Delta \mathrm{A}$ of yam bean slices after $6 \mathrm{~h}$ of osmotic drying. An osmotic solution at $60^{\circ} \mathrm{C}$ with a $\mathrm{SC}$ of $40^{\circ} \mathrm{Brix}$, applying a vacuum pulse of $12 \mathrm{mbar}$ maximized anthocyanin impregnation (6.67 $\mathrm{mg}$ anthocyanin per $\mathrm{g}$ initial dry matter) in tuber slices. The Page equation predicted optimum $W L, S G$ and $\Delta \mathrm{A}$ of yam bean tuber slices during osmotic drying. No relation was found between temperature, sucrose content and vacuum pulse with $\mathrm{K}$ and $\mathrm{n}$ parameters in the Page equation.
\end{abstract}

Keywords: anthocyanin; impregnation; optimization; osmotic drying; yam bean.

Practical Applications: Anthocyanins impregnation of yam bean tuber slices by osmotic dehydration using blackberries juice resulted in a healthier product.

\section{Introduction}

Yam bean (Pachyrhizus erosus (L.) Urb.) is a tuber with a high water content, large amounts of carbohydrates, crude fibers and proteins and a negligibly lipid content. The total caloric value of yam bean tubers is $39 \mathrm{kcal} / 100 \mathrm{~g}$ (Noman et al., 2007), so they could be used in diets that require a low amount of calories. Yam bean tubers can be used also as a solid matrix to impregnate them with nutritious components. In Chiapas (Mexico), an endemic blackberry fruit (Rubusfructicosus sp. L.) is rich in anthocyanins. Anthocyanins are pigments that give many fruits and flowers their blue or red color (Markides, 1982). Berries play an important role in human nutrition as they contain bioactive compounds, such as anthocyanins and phenolic acids (Manganaris et al., 2014). Some of these compounds have antioxidant properties (Wang \& Lin, 2000; Wu et al., 2002) with a large nutritional value (Zhang et al., 2004). For instance, cyanidin-3-glucoside, an anthocyanin found in blackberries (Elisia et al., 2007), has the highest reported antioxidant capacity of all investigated anthocyanins (Wang et al., 1997). Yam bean tuber could be impregnated with juice of $R$. fructicosus sp. thereby increasing its nutritional value (Shi \& Le Maguer, 2002).

Osmotic dehydration processes have been used to impregnate fruit matrixes with different components while at the same time decreasing their moisture (Jiménez-Hernández et al., 2017; Kowalska et al., 2017). Several studies have shown that temperature, sucrose concentration of the osmotic solution (Zapata et al., 2016), slice thickness (Abud-Archila et al., 2008), the ratio of fruit mass versus the osmotic solution volume (Campos et al., 2012), processing time (Germer et al., 2010) and vacuum pulse (Zapata et al., 2016; Gomes-Corrêa et al., 2016; Şahin \& Öztürk, 2016) all have a significant effect on the osmotic dehydration process.

A vacuum pulse applied in the osmotic dehydration process is an important factor to improve the mass transfer between the fruit and the osmotic solution (Zapata et al., 2016; Gomes-Corrêa et al., 2016; Şahin \& Öztürk, 2016). Several studies have been shown that water loss (WL) increased when a vacuum pulse was applied. When a vacuum pulse was applied for 5 to $10 \mathrm{~min}$, the mass transfer rate increased (Zapata et al., 2016; Gomes-Corrêa et al., 2010). Teles et al. (2006) showed that sucrose concentration had a significant effect on mass transfer during osmotic dehydration of melon. An increase in sucrose content of the osmotic solution increased the mass transfer coefficient as the osmotic pressure gradient increased. Zapata et al. (2016) optimized the vacuum pulse osmotic dehydration of cape gooseberry (Physalis peruviana L.). They found that using a sucrose solution of $70^{\circ}$ Brix at $45^{\circ} \mathrm{C}$, applying an agitation of $99.99 \mathrm{rpm}$ with a pressure of $98.92 \mathrm{mbar}$ and 2.87 vacuum pulses reduced weight $47.5 \%$ and water loss $21.1 \%$, while the solid gain was $118.4 \%$. 
Not many studies have been reported that impregnated tubers or fruits with compounds of other fruits. Santacruz-Vazquez et al. (2008) impregnated $\beta$-carotenes in apple slices by osmotic drying and pulsed vacuum osmotic drying. They showed that significant shorter processing times were required with pulsed vacuum osmotic drying compared to osmotic drying and maximum of $6.0 \mathrm{mg} \beta$-carotene $\mathrm{g}^{-1}$ was obtained. Rózek et al. (2009) found that the total phenolic content of osmo-treated food was similar or even higher than that of the richest fruits and vegetables. Rózek et al. (2010) impregnated grape phenolic compounds into apple, banana and potato, and in a model food made of agar gel. They found that the grape phenolic impregnation was controlled by structure and the concentration of the osmo-active solution.

As yam bean has a low nutritional value and the endemic blackberry is consumed only sporadically, yam bean could be impregnated with anthocyanin of the endemic blackberry juice to increase it nutritional value. Therefore, the objective of this work was to determine the effect of temperature, sucrose content and vacuum pulse on WL, SG, color changes $(\Delta E)$ and anthocyanin content $(\triangle A)$ of yam bean slices during osmotic drying using juice of $R$. fructicosus in the osmotic solution.

\section{Materials and methods}

\subsection{Raw materials and osmotic solution}

Yam bean tubers and $R$. fructicosus fruits were obtained from a local supermarket. The tubers were hand washed, peeled and rectangular parallelepipeds $(23 \mathrm{~mm}$ long, $23 \mathrm{~mm}$ wide and $5 \mathrm{~mm}$ thick) were prepared. Mature $R$. fructicosus fruits (approximately $3^{\circ}$ Brix) without physical damage, were selected, washed and kept at $4{ }^{\circ} \mathrm{C}$ until used. The thawed fruits were grounded and filtered to obtain their juice. An osmotic solution was prepared by mixing the juice of $R$. fructicosus with distilled water using a 1:1.5 (juice:water) volume:volume ratio and sucrose. The sucrose concentration was adjusted with commercial sucrose depending on the treatment applied (Table 1).

\subsection{Treatments and experimental design}

Approximately $100 \mathrm{~g}$ yam bean parallelepipeds slices were submerged in $1000 \mathrm{~g}$ osmotic solution in a $3 \mathrm{~L}$ Erlenmeyer flask fitted with a stopper containing a vacuum tube. The osmotic solution was agitated with a magnetic stirrer during the osmotic drying process. The fruit:osmotic solution ratio was 1:10 (w:w) to avoid dilution of osmotic solution (Antonio et al., 2008). A vacuum pulse (VP) was applied first for $10 \mathrm{~min}$ of osmotic drying and atmospheric pressure was re-established thereafter as described by Mujica-Paz et al. (2003a). Tuber slices were sampled at $0,10,60,120,180,240,300$ and $360 \mathrm{~min}$, washed with distilled water to eliminate the superficial sucrose and then cleaned with absorbent paper. The tuber slices were weighted on analytical balance (OHAUS CORPORATION, New Jersey, USA) (sensitivity of $0.0001 \mathrm{~g}$ ) and the moisture content determined in a vacuum oven at $60^{\circ} \mathrm{C}$ until constant weight (Germer et al., 2010).

The $W L$ and $S G$ were calculated using equations 1 and 2:

$$
\begin{aligned}
& W L=\frac{W_{o} X_{o}-W_{t} X_{t}}{D M_{o}} \\
& S G=\frac{W_{o} D M_{o}-W_{t} D M_{t}}{D M_{o}}
\end{aligned}
$$

with $W_{o}$ the weight of the tuber slice $(\mathrm{g})$, the $X_{o}$ moisture content $\left(\mathrm{g} \mathrm{g}^{-1}\right)$ and $D M_{o}$ the dry matter fraction $\left(\mathrm{g} \mathrm{g}^{-1}\right)$ at the beginning of osmotic drying, and $W_{t}, X_{t}$ and $D M_{t}$ during osmotic dehydration.

A yam bean tuber slice was selected to monitor color changes $(\Delta E)$. The color of yam bean tuber was measured with a Color Tec (Colour-Tec-PCM, Riga, Latvia) colorimeter supplied with an optical sensor of $8 \mathrm{~mm}$ using CIE-Lab system. Color changes $(\Delta E)$ were calculated using equation 3:

$$
\Delta E=\sqrt{\left(L^{*}-L_{t}\right)^{2}+\left(a^{*}-a_{t}\right)^{2}+\left(b^{*}-b_{t}\right)^{2}}
$$

where $L^{*}, a^{\star}$ and $b^{*}$ the Hunter parameters of the fresh yam bean tuber and $L_{t}, a_{t}$ and $b_{t}$ during osmotic dehydration. $\Delta \mathrm{L}$ and $\Delta \mathrm{a}$

\begin{tabular}{|c|c|c|c|c|c|c|c|}
\hline \multirow{3}{*}{ Treatment } & \multirow{3}{*}{$\begin{array}{c}\text { Temperature } \\
\left({ }^{\circ} \mathrm{C}\right)\end{array}$} & \multirow{3}{*}{$\begin{array}{l}\text { Sucrose content } \\
\left({ }^{\circ} \text { Brix }\right)\end{array}$} & \multirow{3}{*}{$\begin{array}{l}\text { Vacuum pulse } \\
\text { (mbar) }\end{array}$} & WL & SG & WL & SG \\
\hline & & & & \multicolumn{2}{|c|}{$10 \min$} & \multicolumn{2}{|c|}{$360 \mathrm{~min}$} \\
\hline & & & & \multicolumn{4}{|c|}{$-----\left(\mathrm{g} \mathrm{g}^{-1}\right)----$} \\
\hline 1 & 60 & 60 & 300 & $2.65 \pm 0.26^{\mathrm{a}}$ & $0.73 \pm 0.12$ & $6.1 \pm 0.39$ & $1.73 \pm 0.07$ \\
\hline 2 & 60 & 50 & 600 & $1.76 \pm 0.18$ & $0.60 \pm 0.05$ & $4.98 \pm 0.37$ & $1.55 \pm 0.15$ \\
\hline 3 & 50 & 40 & 0 & $1.60 \pm 0.26$ & $0.38 \pm 0.07$ & $4.10 \pm 0.40$ & $1.19 \pm 0.14$ \\
\hline 4 & 40 & 40 & 300 & $1.66 \pm 0.21$ & $0.48 \pm 0.23$ & $5.46 \pm 0.31$ & $1.18 \pm 0.16$ \\
\hline 5 & 60 & 50 & 0 & $1.90 \pm 0.23$ & $0.44 \pm 0.03$ & $4.73 \pm 0.26$ & $1.28 \pm 0.16$ \\
\hline 6 & 60 & 40 & 300 & $1.70 \pm 0.40$ & $0.53 \pm 0.02$ & $4.71 \pm 0.81$ & $1.60 \pm 0.18$ \\
\hline 7 & 40 & 50 & 0 & $1.61 \pm 0.27$ & $0.27 \pm 0.02$ & $4.58 \pm 0.67$ & $0.85 \pm 0.14$ \\
\hline 8 & 40 & 50 & 600 & $1.63 \pm 0.01$ & $0.50 \pm 0.08$ & $5.35 \pm 0.34$ & $1.45 \pm 0.19$ \\
\hline 9 & 40 & 60 & 300 & $3.38 \pm 1.00$ & $0.87 \pm 0.02$ & $7.61 \pm 1.07$ & $1.86 \pm 0.15$ \\
\hline 10 & 50 & 60 & 600 & $2.91 \pm 0.70$ & $0.53 \pm 0.11$ & $6.87 \pm 0.57$ & $1.56 \pm 0.12$ \\
\hline $11,14,15$ & 50 & 50 & 300 & $1.66 \pm 0.45$ & $0.49 \pm 0.10$ & $4.94 \pm 0.92$ & $1.52 \pm 0.35$ \\
\hline 12 & 50 & 60 & 0 & $2.41 \pm 0.34$ & $0.54 \pm 0.08$ & $5.85 \pm 0.60$ & $1.41 \pm 0.22$ \\
\hline 13 & 50 & 40 & 600 & $1.65 \pm 0.10$ & $0.53 \pm 0.17$ & $5.11 \pm 0.50$ & $1.60 \pm 0.29$ \\
\hline
\end{tabular}
values were calculated using equations 4 and 5:

Table 1. Water loss $(W L)$ and solid gain $(S G)$ of yam bean tuber slices after vacuum pulse (10 min) and 6 h of osmotic dehydration.

${ }^{a}$ Results are the average of three independent experiments \pm standard deviations. 
$\Delta L=\left(L^{*}-L_{t}\right)$

$\Delta a=\left(a^{*}-a_{t}\right)$

A $0.5 \mathrm{~g}$ sub-sample of an impregnated yam bean was macerated with $50 \mathrm{~mL}$ methanol- $\mathrm{HCl} 1 \%$ for $30 \mathrm{~min}$. The macerated yam bean was stored at $-20^{\circ} \mathrm{C}$ for $20 \mathrm{~h}$, centrifuged at 1509 (x g) for $10 \mathrm{~min}$ (centrifuge 5810-R, Hamburg, Germany) and the anthocyanin concentration measured in the supernatant at $510 \mathrm{~nm}$ using a Cole Parmer UV-2100 Spectrophotometer (Cole Parmer Instruments Company, Illinois, USA). Anthocyanins $(\Delta \mathrm{A})$ were quantified using equation 6 :

$\Delta A\left(m g g^{-1}\right)=\frac{A^{*} M W^{*} D F^{*} 1000^{*} v}{\varepsilon^{*} l^{*} m}$

with: $A$ the absorbance (510 nm), MW the molecular weight (449 $\mathrm{g} \mathrm{mol}^{-1}$ ), DF dilution factor, $v$ the volume of extracting solution, $\mathrm{m}$ the dry matter of the sample in time $\mathrm{t}$ and $\varepsilon$ the molar absorption coefficient $\left(26900 \mathrm{~L} \mathrm{~cm}^{-1} \mathrm{~mol}^{-1}\right)$. The molecular weight used (449 $\mathrm{g} \mathrm{mol}^{-1}$ ) was that of cyanidin-3-glucoside, i.e. the main anthocyanin found in R. fructicosus (Elisia et al., 2007).

\subsection{Experimental method and statistical analysis}

The response surface methodology was used to determine the effect of temperature (T), i.e. 40,50 or $60^{\circ} \mathrm{C}$, sucrose content (SC), i.e. 40,50 or $60^{\circ} \mathrm{Brix}$, and with/without vacuum pulse, i.e. 0,300 and 600 mbar on $W L, S G, \Delta \mathrm{E}$ and $\Delta \mathrm{A}$ of yam bean tuber slices during osmotic drying. A Box-Behnken experimental design with three blocks and three replicates of the central point treatment was applied (Table 1). The statistical analysis was done with Statgraphics Centurion XV (StatPoint Technologies, Inc., Virginia, USA). The $W L, S G, \Delta \mathrm{E}, \Delta \mathrm{A}$ data after $6 \mathrm{~h}$ of osmotic drying were analyzed by multiple regression analyses with the least square method (equation 7):

$Y=\beta_{o}+\beta_{1} V P+\beta_{2} T+\beta_{3} S C+\beta_{4} V P^{2}+\beta_{5} V P * T+$

$\beta_{6} V P^{*} S C+\beta_{7} T^{2}+\beta_{8} S C^{*} T+\beta_{9} S C^{2}$

where $\beta_{i}$ were the coefficients to identify, $V P$ the vacuum pulse (mbar), $S C$ the sucrose content $\left({ }^{\circ}\right.$ Brix) and $T\left({ }^{\circ} \mathrm{C}\right)$ the temperature of the osmotic solution. The $\mathrm{R}^{2}$ were calculated for each equation.

The $W L, S G$ and $\Delta \mathrm{A}$ during osmotic drying were also fitted with Page's model (equation 8), which is a simplification of the Fick's equation (Chambi et al., 2016):

$\frac{X(t)-X e q}{X o-X e q}=\exp \left(-K t^{n}\right)$

where $X(t)$ was the $W L, S G$ or $\Delta \mathrm{A}$ of yam bean tuber slices during time of osmotic drying, $X o$ the initial value, $X e q$ the equilibrium value, $\mathrm{K}$ and $\mathrm{n}$ Page's parameters for $W L, S G$ or $\Delta \mathrm{A}, t$ the time in $\mathrm{h}$. The $\mathrm{R}^{2}$ were calculated for each osmotic drying kinetics. Constant $K$ and $n$ were determined by non-linear estimation using the Statgraphics Centurion XV (StatPoint Technologies, Inc., Virginia, USA).

\section{Result and discussions}

The osmotic drying of the yam bean resulted in a water loss varied between 1.60 and $3.38 \mathrm{~g} \mathrm{~g}^{-1}$, while $S G$ between 0.27 and $0.87 \mathrm{~g} \mathrm{~g}^{-1}$ after $10 \mathrm{~min}$ (Table 1). After $360 \mathrm{~min}$, WL varied between 4.10 and $7.66 \mathrm{~g} \mathrm{~g}^{-1}$ and SG between 0.85 and $1.86 \mathrm{mg} \mathrm{g}^{-1}$. The largest $W L$ was found in treatment 9 and the lowest in treatment 3, while similar results were obtained for $S G$ after $10 \mathrm{~min}$. After $360 \mathrm{~min}$, the largest $W L$ was found in treatment 9 and the lowest in treatment 3, while the largest $S G$ was found in treatment 9 and the lowest in treatment 7.

The $W L$ and $S G$ increased with immersion time, but $W L$ was higher generally than $S G$. Similar results were found with apples (Santacruz-Vazquez et al., 2008) and melons (Teles et al., 2006). The $W L$ increased with sucrose concentration (Figure 1(a)), but $W L$ was higher when a VP of 600 mbar was applied (Figure $1(\mathrm{~b})$ ). When a syrup with a high sugar concentration was used, the osmotic pressure gradient between the fruit and the solution increased also; thus increasing the driving force of mass transfer. These results were similar to those reported by Gomes-Corrêa et al. (2010). They reported that when a higher concentration was used in the solution, an increase in $W L$ of osmotically dehydrated guavas was found. When osmotic drying was applied at atmospheric pressure, the $S G$ increased with sucrose content in the osmotic solution, but no significant differences were found when a VP was applied (Figure 1(a)). This might be explained by a change in cell membrane permeability of the vegetable tissue that lead to a gradual increase in the absorption of the solids. However, these results contrast with other studies. For instance, Pereira et al. (2006), Germer et al. (2010) and Gomes-Corrêa et al. (2010) found a negative effect when the solute concentration increased, i.e. the $S G$ decreased when a higher sucrose concentration was used. They suggested that this could be explained by the formation of a superficial dense layer of solutes on the product acting as a barrier against penetration of the solutes into the food, which makes solutes mass transfer more difficult resulting in a lower solid uptake in yam bean tissue.

Analysis of variance showed that T, SC and VP had a significant effect on $W L$ after 6 h of osmotic dehydration $(\mathrm{P}<0.05)$ (Table 2$)$. Similar results were obtained with mango (Madamba \& Lopez 2002) and pineapple (Saputra, 2001). Permeability of the cellular membrane changed when the temperature increased allowing a better exchange of water, sucrose and anthocyanins in the yam bean slices. Moreover, when the temperature increased, the viscosity of the solution decreased so that the mass transfer rate could increase. Vacuum pulse had a significant effect on $W L$ and $S G$ after $6 \mathrm{~h}(\mathrm{P}<0.05)$.

Hydrodynamics at the beginning of the osmotic drying explain that the WL of yam bean slices increased with the application of a vacuum pulse. With the application of the vacuum pressure for $10 \mathrm{~min}$, the gas occluded in the intercellular spaces of the vegetable tissues was removed and then, when the atmospheric pressure was restored, the pores of the food material were filled by the osmotic solution (Gomes-Corrêa et al., 2010). Vacuum deformed the tissue structure facilitating the penetration of the osmotic solution while increasing the contact area for mass transfer (Mujica-Paz et al., 2003a). 

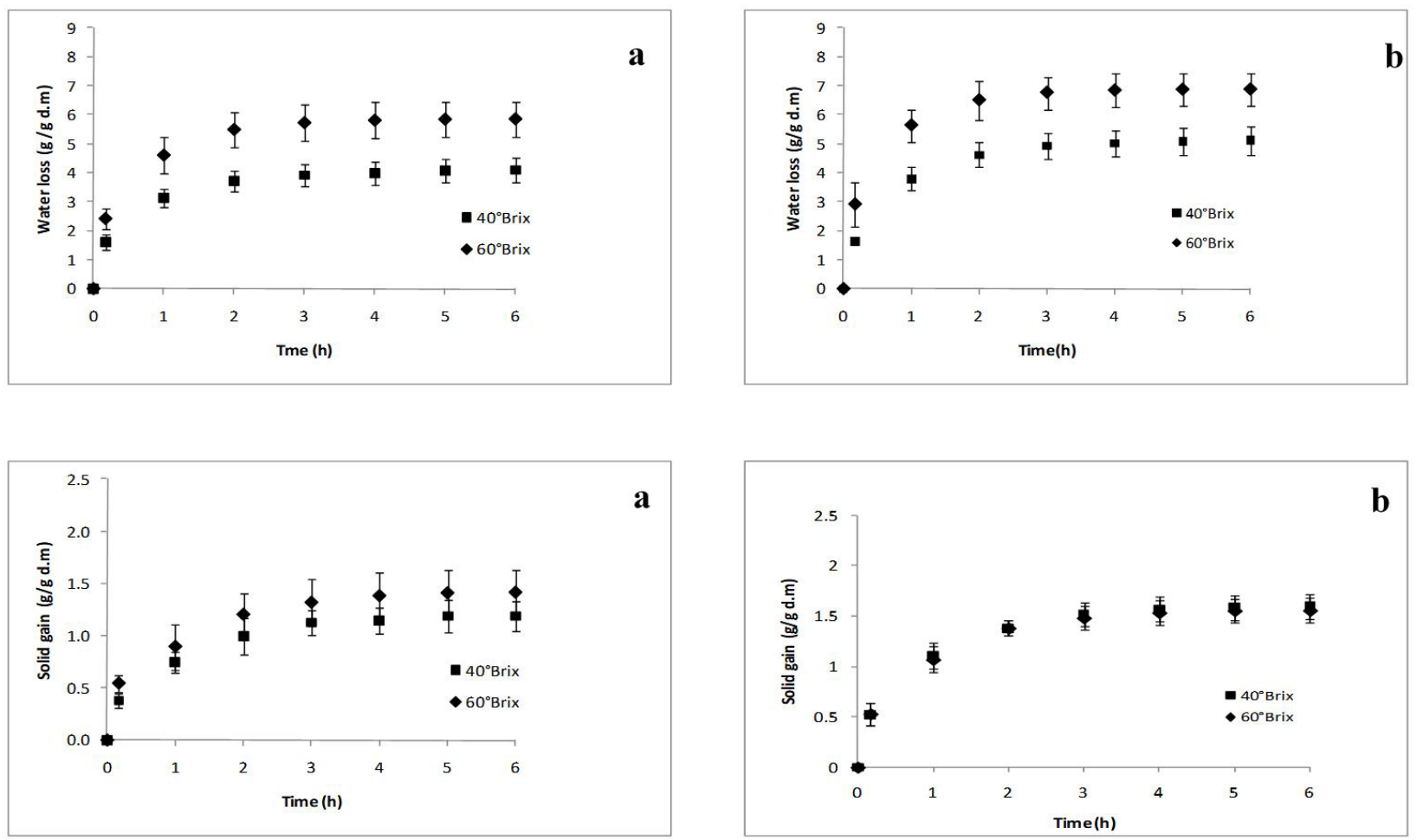

Figure 1. Effect of sucrose content on water loss and solid gain of yam bean tuber slices during osmotic drying. (a) atmospheric pressure and (b) vacuum pulse of $600 \mathrm{mbar}$ at $50 \mathrm{oC}$.

Table 2. P-values for water loss (WL), solid gain (SG), anthocyanin impregnated $(\Delta \mathrm{A})$, color changes $(\Delta \mathrm{E})$, luminosity changes $(\Delta \mathrm{L})$ and a values changes $(\Delta \mathrm{a})$ of yam bean tuber slices after 6 hours of osmotic dehydration as obtained after an analysis of variance (ANOVA).

\begin{tabular}{lcccccc}
\hline \multirow{2}{*}{ Factor } & \multicolumn{5}{c}{ P-values } \\
\cline { 2 - 7 } & $\mathrm{WL}$ & $\mathrm{SG}$ & $\Delta \mathrm{A}$ & $\Delta \mathrm{E}$ & $\Delta \mathrm{L}$ & \multicolumn{1}{c}{$\Delta \mathrm{a}$} \\
\hline Vacuum pulse & $<0.0001$ & 0.0003 & 0.2300 & 0.0812 & 0.0699 & 0.5549 \\
Temperature & 0.0490 & 0.1097 & 0.2026 & 0.3761 & 0.0085 & 0.0005 \\
Sucrose content & 0.0148 & 0.0194 & 0.0025 & 0.000 & 0.0001 & 0.1289 \\
Block & 0.3605 & 0.5940 & 0.5024 & 0.3667 & 0.35911 & 0.1872 \\
\hline
\end{tabular}

The VP and SC had a significant effect on $S G$, but not $\mathrm{T}$ $(\mathrm{P}<0.05)$ (Table 2). Mujica-Paz et al. (2003b) reported that during osmotic dehydration at $25^{\circ} \mathrm{C}$, the $\mathrm{SG}$ of melon and apple increased when the sucrose content of the solution increased. In general, the $S G$ of yam bean slices osmotically dried when a VP was applied, was higher than samples osmotically dried at atmospheric pressure (without vacuum pulse). A vacuum pulse applied during the osmotic dehydration process promotes and facilitates impregnation (Chiralt \& Talens, 2005). The osmotic solution entered easily when a vacuum pulse was applied. Analysis of variance showed that sucrose content had a significant effect on the concentrations of impregnated anthocyanin and color changes at the end of osmotic dehydration process $(\mathrm{P}<0.05)$ (Table 2). After 10 min of osmotic drying, the amount of $\Delta \mathrm{A}$ ranged from 0.69 to $1.45 \mathrm{mg} \mathrm{g}^{-1}$ and between 3.74 and $6.27 \mathrm{mg} \mathrm{g}^{-1}$ at the end of the process. After 10 min of osmotic drying, $\Delta E$ varied between 7.29 and 19.41 and at the end $(6 \mathrm{~h})$ between 38.79 and 48.07 .

The $\Delta \mathrm{A}$ in yam bean tuber slices increased when the SC decreased in the solution (Figure 2). When lower sucrose contents were used, the viscosity of osmotic solution containing anthocyanin probably decreased, facilitating the penetration of the osmotic solution into the matrix. At a constant $50^{\circ} \mathrm{C}$ and atmospheric pressure, the $\Delta \mathrm{A}$ was higher than in yam bean slices osmotic dehydrated applying a VP of $600 \mathrm{mbar}$ (Figure 2(a) and (b)).

A vacuum pulse applied for the first 10 min of osmotic drying did not increase the $\Delta \mathrm{A}$ during the subsequent osmotic drying process. Fito et al. (1996) found that a high vacuum pressure could irreversible deform tissue, reducing the open space available for impregnation. However, these results are different from those reported by others. For instance, Santacruz-Vazquez et al. (2008) impregnated apple slices with $\beta$-carotenes and found that a higher impregnation was obtained when a vacuum pulse of $130 \mathrm{mbar}$ was applied. This could be due to differences in porosity between yam bean tuber and apple slices. The initial porosity of apple varies between 0.15 (Krokida \& Maroulis, 1997) and 0.22 (Rahman et al., 2005), while between 0.03 (Mavroudis et al., 1998 ) and 0.08 for potato (Krokida \& Maroulis, 1997). Abud Archila et al (2008) reported that initial porosity of yam bean was 0.07 , for that we think that the vacuum pulse could to have similar effects on yam bean tuber slices. 


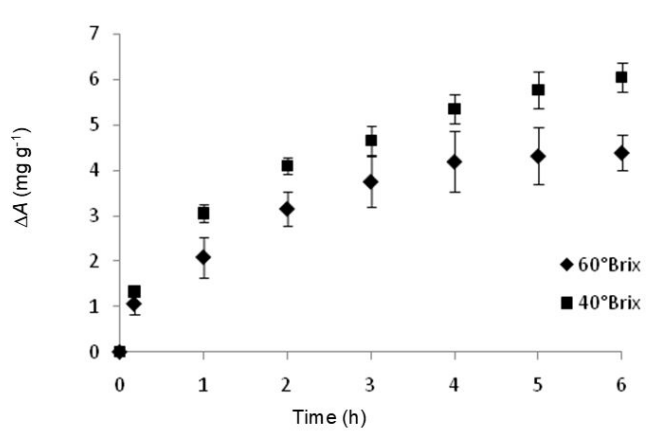

(a)

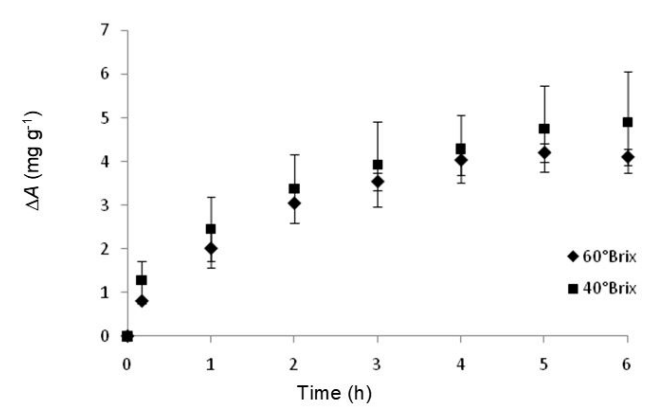

(b)

Figure 2. Effect of sucrose content on anthocyanin impregnated $(\Delta \mathrm{A})$ of yam bean tuber slices during osmotic drying. (a) atmospheric pressure and (b) vacuum pulse of $600 \mathrm{mbar}$ at $5{ }^{\circ} \mathrm{C}$.
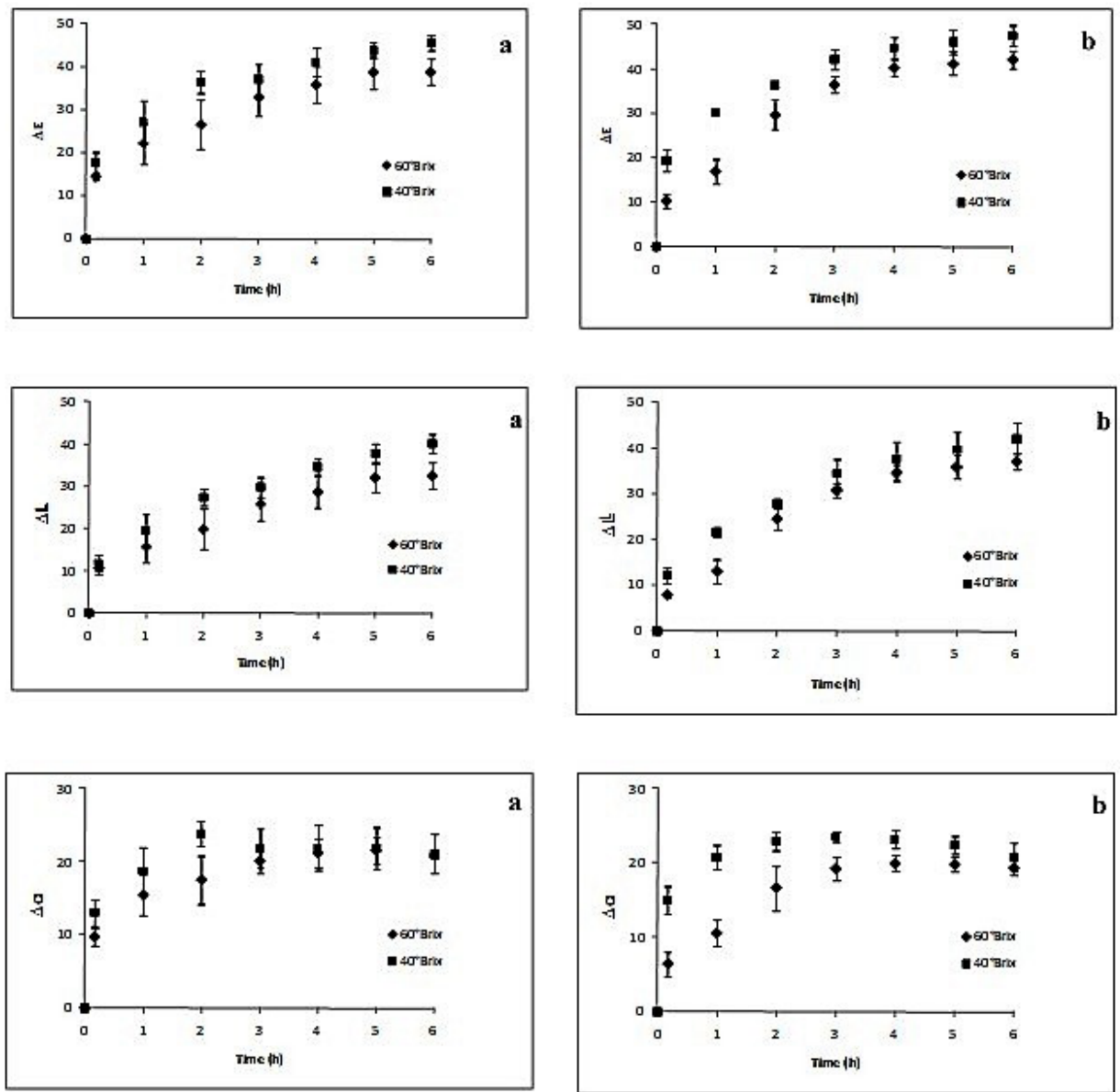

Figure 3. Effect of sucrose content on color changes $(\Delta \mathrm{E})$, luminosity changes $(\Delta \mathrm{L})$ and a values changes $(\Delta \mathrm{a})$ of yam bean tuber slices during osmotic drying. (a) Atmospheric pressure and (b) vacuum pulse of $600 \mathrm{mbar}$ at $50^{\circ} \mathrm{C}$. 
Table 3. Regression coefficients and P-values of the second-order equation fitted to water loss (WL), solid gain (SG), anthocyanin impregnated $(\triangle \mathrm{A})$ and color changes $(\Delta \mathrm{E})$ of yam bean tuber slices after 6 hours of osmotic dehydration.

\begin{tabular}{|c|c|c|c|c|c|c|c|c|}
\hline \multirow{2}{*}{ Source } & \multicolumn{2}{|c|}{$W L$} & \multicolumn{2}{|c|}{$S G$} & \multicolumn{2}{|c|}{$\Delta \mathrm{A}$} & \multicolumn{2}{|c|}{$\Delta \mathrm{E}$} \\
\hline & Coefficient & P-value & Coefficient & $\mathrm{P}$-value & Coefficient & P-value & Coefficient & $\mathrm{P}$-value \\
\hline B: Constant & 22.1595 & & -2.3130 & & 1.3423 & & 9.1123 & \\
\hline $\mathrm{T}$ : Temperature & -0.1592 & 0.0327 & 0.1278 & 0.0324 & 0.1046 & 0.0697 & -0.1065 & 0.1785 \\
\hline SC: Sucrose content & -0.6266 & 0.0000 & $-2.70 \times 10^{-2}$ & 0.0113 & 0.1222 & 0.0003 & 1.802 & 0.0001 \\
\hline VP: Vacuum Pulse & $5.26 \times 10^{-3}$ & 0.0102 & $4.3 \times 10^{-3}$ & 0.0005 & $6.125 \times 10^{-3}$ & 0.3500 & $-3.55 \times 10^{-3}$ & 0.0666 \\
\hline $\mathrm{T}^{2}$ & $2.38 \times 10^{-3}$ & 0.2571 & $-4.08 \times 10^{-4}$ & 0.5533 & $1.40 \times 10^{-3}$ & 0.5897 & $2.66 \times 10^{-6}$ & 0.9998 \\
\hline $\mathrm{SC}^{\star} \mathrm{T}$ & $-1.9 \times 10^{-3}$ & 0.3343 & $-1.37 \times 10^{-3}$ & 0.0437 & $-4.67 \times 10^{-3}$ & 0.0687 & $2.73 \times 10^{-3}$ & 0.7541 \\
\hline $\mathrm{VP}^{\star} \mathrm{T}$ & $-4.4 \times 10^{-5}$ & 0.5114 & $-2.71 \times 10^{-5}$ & 0.2229 & $-1.5 \times 10^{-4}$ & 0.0798 & $1.79 \times 10^{-4}$ & 0.5393 \\
\hline $\mathrm{SC}^{2}$ & $8.13 \times 10^{-3}$ & 0.0004 & $1.14 \times 10^{-3}$ & 0.1017 & $1.91 \times 10^{-4}$ & 0.9414 & $-2.25 \times 10^{-2}$ & 0.0174 \\
\hline $\mathrm{VP}^{*} \mathrm{SC}$ & $8.94 \times 10^{-8}$ & 0.9989 & $-2.22 \times 10^{-5}$ & 0.3159 & $7.15 \times 10^{-5}$ & 0.3945 & $1.15 \times 10^{-4}$ & 0.6929 \\
\hline $\mathrm{VP}^{2}$ & $-3 \times 10^{-6}$ & 0.2017 & $-2.16 \times 10^{-6}$ & 0.0071 & $-4.62 \times 10^{-6}$ & 0.1169 & $-1.21 \times 10^{-5}$ & 0.2338 \\
\hline $\mathrm{R}^{2}$ & $67.54 \%$ & & $56.72 \%$ & & $47.09 \%$ & & $49.1 \%$ & \\
\hline
\end{tabular}

${ }^{*}=$ multiplication.
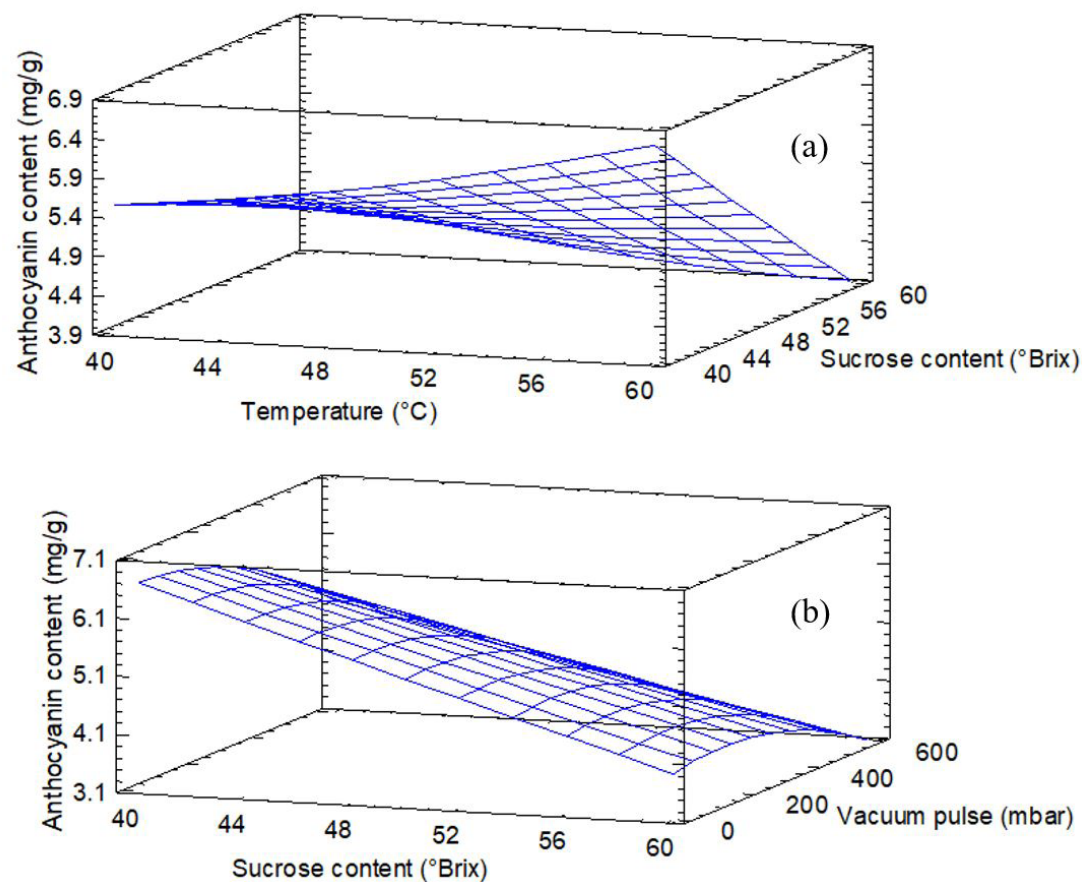

Figure 4. Response surfaces of anthocyanin impregnated $(\Delta \mathrm{A})$ in yam bean tuber slices osmodehydrated at $\mathrm{VP}$ of $12.05 \mathrm{mbar}(\mathrm{a})$ and at $60^{\circ} \mathrm{C}(\mathrm{b})$.

found on the amount of $\Delta \mathrm{A}$ at $60^{\circ} \mathrm{C}(\mathrm{P}<0.01)$ (Figure $\left.4(\mathrm{~b})\right)$. The amount of anthocyanin that impregnated the yam bean slice was used to optimize the osmotic drying process. For that, response surfaces of anthocyanin impregnated $(\Delta \mathrm{A})$ in yam bean tuber slices osmodehydrated were made (Figure 4). A maximum anthocyanin of $6.67 \mathrm{mg}$ anthocyanin $\mathrm{g}^{-1}$ initial dry matter content was obtained with an osmotic solution with a $40^{\circ}$ Brix sucrose content and applying a VP of $12.05 \mathrm{mbar}$ at $59.86^{\circ} \mathrm{C}\left(\sim 60^{\circ} \mathrm{C}\right)$.

Page's coefficients showed a large variation. The $K$ values varied between 0.79 and 1.84 for $W L$ and 0.55 and 1.26 for $S G$, while the $n$ values varied between 0.76 and 1.13 for $W L$ and 0.81 and 1.25 for $S G$ (Table 4). The $K$ parameters of $W L$ ad $S G$ were higher than those of anthocyanin impregnation, while $\mathrm{n}$ values for WL and SG were close to 1 . All $\mathrm{R}^{2}$ values were close to 98 (Table 4 ). These $K$ and $n$ values are different from those reported by Park et al. (2002) for pear osmotic dehydration at different temperatures, different concentrations of sucrose and without the application of vacuum. They reported $K$ values that ranged between $0.36 \times 10^{-3}$ to $10.66 \times 10^{-3}$ and $n$ values that varied from 0.11 to 0.89 , while Antonio et al. (2008) reported $K$ and $n$ values of 0.07 and 0.62 for $W L$ and 0.02 and 0.73 for $S G$ of sweet potato osmose-hydrated using a sucrose content of $50 \% \mathrm{w} / \mathrm{w}$ at $40^{\circ} \mathrm{C}$. The $K$ varied between 0.17 and 0.76 for anthocyanin impregnated, and $n$ between 0.97 and 1.93. Kaushal \& Sharma (2014) reported $n$ values between 1.17 and 1.39 and $K$ values between 0.29 and $0.3510^{-3}$ for osmo-convective dehydration kinetics of jackfruit. Darvishi et al (2014) found similar $K$ values (ranging from 0.14 and 0.55 ) and $n$ values (ranging between 
Table 4. Page's coefficients ( $K$ and $n$ ) for water loss $(W L)$, solid gain $(S G)$ and anthocyanin impregnated $(\Delta \mathrm{A})$ in yam bean tuber slices during osmotic drying for several temperatures (T), sucrose content (SC) and vacuum pulse (VP) applied.

\begin{tabular}{|c|c|c|c|c|c|c|c|c|c|c|c|}
\hline \multirow{2}{*}{$\mathrm{T}$} & \multirow{2}{*}{ SC } & \multirow{2}{*}{$\mathrm{VP}$} & \multicolumn{3}{|c|}{$W L$} & \multicolumn{3}{|c|}{$S G$} & \multicolumn{3}{|c|}{$(\Delta A)$} \\
\hline & & & $K$ & $n$ & $\mathrm{R}^{2}$ & $K$ & $n$ & $\mathrm{R}^{2}$ & $K$ & $n$ & $\mathrm{R}^{2}$ \\
\hline 60 & 60 & 300 & 1.83 & 0.79 & 99.9 & 1 & 0.91 & 97 & 0.70 & 1.2 & 98 \\
\hline 60 & 50 & 600 & 1.49 & 0.82 & 99.6 & 1.08 & 0.87 & 98 & 0.47 & 1.39 & 97 \\
\hline 50 & 40 & 0 & 1.33 & 0.77 & 97 & 0.95 & 0.82 & 99 & 0.26 & 1.66 & 97 \\
\hline 40 & 40 & 300 & 0.79 & 1.08 & 98 & 0.96 & 0.83 & 96 & 0.25 & 1.42 & 98 \\
\hline 60 & 50 & 0 & 1.48 & 0.80 & 99.6 & 0.92 & 1.01 & 96 & 0.46 & 1.26 & 99 \\
\hline 40 & 50 & 600 & 1.07 & 0.94 & 98 & 0.56 & 1.21 & 98 & 0.19 & 1.89 & 99 \\
\hline 40 & 60 & 300 & 0.92 & 1.09 & 98 & 0.76 & 1.2 & 99 & 0.43 & 1.45 & 99 \\
\hline 50 & 60 & 600 & 1.57 & 0.82 & 99 & 1.26 & 0.84 & 99 & 0.31 & 1.6 & 98 \\
\hline 50 & 50 & 300 & 1.05 & 1.13 & 98 & 0.90 & 0.92 & 98 & 0.21 & 1.58 & 99 \\
\hline 50 & 60 & 0 & 1.37 & 1.01 & 99 & 0.75 & 1.25 & 99 & 0.76 & 0.97 & 99 \\
\hline
\end{tabular}

$K$ and $n$ coefficients for water loss $(W L)$, solid gain $(S G)$ and anthocyanin impregnated $(\triangle \mathrm{A})$ are the average of three independent experiments.

1.38 and 1.82) for microwave drying of pepper. The $K$ and $n$ parameters showed no clear pattern when the temperature, sucrose content or vacuum pulse were altered (Table 4). Similar results were obtained by Antonio et al. (2008) for osmotic dehydration of sweet potato using ternary solutions. They reported no trend when the solution concentration was increased at a constant temperature or when the temperature was increased with the same solution concentration. Simpson et al. (2017) reported the possible meaning of $K$ and $n$ in Page's equation. The $K$ parameter could be related to the diffusion coefficient and the geometry of the sample and $n$ to diffusion and food microstructure $(n>1$ "super" diffusion and $n<1$ "sub" diffusion). Then, for $W L$ and $S G$ values of $n$, a subdiffusion process could be observed, while a super-diffusion could be expected for anthocyanin impregnated.

\section{Conclusion}

The osmotic drying process allowed to impregnate yam bean tuber slices with anthocyanin from $R$. fructicosus juice. The response surface methodology allowed to obtain better conditions for impregnation by osmotic drying. An osmotic solution at $60^{\circ} \mathrm{C}$ with a sucrose content of $40^{\circ} \mathrm{Brix}$ and applying a vacuum pulse of $12 \mathrm{mbar}$ for $10 \mathrm{~min}$ at the beginning of osmotic drying maximized anthocyanin impregnation in yam bean tuber slices to $6.67 \mathrm{mg}$ anthocyanin $\mathrm{g}^{-1}$ initial dry matter. Page's equation fitted the experimental data better than other models applied. The results obtained in this study suggest that osmotic drying using sucrose - $R$. fructicosus juice as osmotic agent bettered the functional characteristics of yam bean tuber slices. However, further research is required to test the functional activity of anthocyanin impregnated in yam bean slices and to determine their sensorial properties.

\section{References}

Abud-Archila, M., Vazquez-Mandujano, D. G., Ruiz-Cabrera, M. A., Grajales-Lagunes, A., Moscosa-Santillán, M., Ventura-Canseco, L. M. C., Gutierrez-Miceli, F. A., \& Dendooven, L. (2008). Optimization of osmotic dehydration of Yam bean (Pachyrhizus erosus) using an orthogonal experimental design. Journal of Food Engineering, 84(3), 413-419. http://dx.doi.org/10.1016/j.jfoodeng.2007.06.003.

Antonio, G. C., Azoubel, P. M., Murr, F. E., \& Park, K. J. (2008). Osmotic dehydration of sweet potato (Ipomoea batatas) in ternary solutions. Ciência e Tecnologia de Alimentos, Campinas, 28(3), 696-701. http:// dx.doi.org/10.1590/S0101-20612008000300028.

Campos, C. D. M., Sato, A. C. K., Tonon, R. V., Hubinger, M. D., \& Cunha, R. L. (2012). Effect of process variables on the osmotic dehydration of star-fruit slices. Ciência e Tecnologia de Alimentos, Campinas, 32(2), 357-365. http://dx.doi.org/10.1590/S0101-20612012005000034.

Chambi, H. N., Lima, W. C. V., \& Schmidt, F. L. (2016). Osmotic dehydration of yellow melon using red grape juice concentrate. Ciência e Tecnologia de Alimentos, Campinas, 36(3), 468-475. http:// dx.doi.org/10.1590/1678-457X.01416.

Chiralt, A., \& Talens, P. (2005). Physical and chemicals changes induced by osmotic dehydration in plant tissues. Journal of Food Engineering, 67(1-2), 167-177. http://dx.doi.org/10.1016/j.jfoodeng.2004.05.055.

Darvishi, H., Asl, A. R., Asghari, A., Azadbakht, M., Najafi, G., \& Khodaei, J. (2014). Study of the drying kinetics of pepper. Journal of the Saudi Society of Agricultural Sciences, 13(2), 130-138. http:// dx.doi.org/10.1016/j.jssas.2013.03.002.

Elisia, I., Hu, C., Popovich, D. G., \& Kitts, D. D. (2007). Antioxidant assessment of an anthocyanin-enriched blackberry extract. Journal of Food Chemistry, 101(3), 1052-1058. http://dx.doi.org/10.1016/j. foodchem.2006.02.060.

Fito, P., Andres, A., Chiralt, A., \& Pardo, A. (1996). Coupling of hydrodynamic mechanism and deformation-relaxation phenomenon during vacuum treatments in solid porous food-liquid systems. Journal of Food Engineering, 27(3), 229-240. http://dx.doi.org/10.1016/02608774(95)00005-4.

Germer, S. P. M., Queiroz, M. R., Aguirre, J. M., Berbari, S. A., \& Anjos, V. D. (2010). Process variables in the osmotic dehydration of sliced peaches. Ciência e Tecnologia de Alimentos, Campinas, 30(4), 940948. http://dx.doi.org/10.1590/S0101-20612010000400016.

Gomes-Corrêa, J. L., Ernesto, D. B., \& Mendonca, K. S. (2016). Pulsed vacuum osmotic dehydration of tomatoes: sodium incorporation reduction and kinetics modeling. Lebensmittel-Wissenschaft + Technologie, 71, 17-24. http://dx.doi.org/10.1016/j.lwt.2016.01.046. 
Gomes-Corrêa, J. L., Pereira, L. M., Vieria, G. S., \& Hubinger, M. D. (2010). Mass transfer kinetics of pulsed vacuum osmotic dehydration of guavas. Journal of Food Engineering, 96(4), 498-504. http://dx.doi. org/10.1016/j.jfoodeng.2009.08.032.

Jiménez-Hernández, J., Estrada-Bahena, E. B., Maldonado-Astudillo, Y. I., Talavera-Mendoza, O., Arámbula-Villa, G., Azuara, E., ÁlvarezFitz, P., Ramírez, M., \& Salazar, R. (2017). Osmotic dehydration of mango with impregnation of inulin and piquin-pepper oleoresin. LWT - Food Science and Technology, 79, 609-615. http://dx.doi. org/10.1016/j.lwt.2016.11.016

Kaushal, P., \& Sharma, H. K. (2014). Osmo-convective dehydration kinetics of jackfruit (Artocarpus heterophyllus). Journal of the Saudi Society of Agricultural Sciences, 15(2), 118-126. http://dx.doi. org/10.1016/j.jssas.2014.08.001.

Kowalska, H., Marzec, A., Kowalska, J., Ciurzynska, A., Czajkowska, K., Cichowska, J., Rybak, K., \& Lenart, A. (2017). Osmotic dehydration of Honeoye strawberries in solutions enriched with natural bioactive molecules. Lebensmittel-Wissenschaft + Technologie, 85, 500-505. http://dx.doi.org/10.1016/j.lwt.2017.03.044.

Krokida, M. K., \& Maroulis, Z. B. (1997). Effect of drying method on shrinkage and porosity. Drying Technology, 15(10), 2441-2458. http://dx.doi.org/10.1080/07373939708917369.

Madamba, P., \& Lopez, R. I. (2002). Optimization of the osmotic dehydration of mango (Magnifera Indica L.) slices. Drying Technology, 20(6), 1227-1242. http://dx.doi.org/10.1081/DRT-120004049.

Manganaris, G. A., Goulas, V., Vicente, A. R., \& Terry, L. A. (2014). Berry antioxidants: small fruits providing large benefits. Journal of the Science of Food and Agriculture, 94(5), 825-833. http://dx.doi. org/10.1002/jsfa.6432. PMid:24122646.

Markides, P. (1982). Anthocyanins as Food Colors. London: Academic Press.

Mavroudis, N. E., Gekas, V., \& Sjoholm, I. (1998). Osmotic dehydration of apples. shrinkage phenomena and the significance of initial structure on mass transfer rates. Journal of Food Engineering, 38(1), 101-123. http://dx.doi.org/10.1016/S0260-8774(98)00090-9.

Mujica-Paz, H., Valdez-Fragoso, A., Lopez-Malo, A., Palou, E., \& WeltiChanes, J. (2003a). Impregnation and osmotic dehydration of some fruits: effect of the vacuum pressure and syrup concentration. Journal of Food Engineering, 57(4), 305-314. http://dx.doi.org/10.1016/ S0260-8774(02)00344-8.

Mujica-Paz, H., Valdez-Fragoso, A., Lopez-Malo, A., Palou, E., \& Welti-Chanes, J. (2003b). Impregnation properties of some fruits at vacuum pressure. Journal of Food Engineering, 56(4), 307-314. http://dx.doi.org/10.1016/S0260-8774(02)00155-3.

Noman, A. S. M., Hoque, M. A., Haque, M. M., Pervin, F., \& Karim, M. R. (2007). Nutritional and anti-nutritional components in Pachyrhizus erosus L. tuber. Food Chemistry, 102(4), 1112-1118. http://dx.doi. org/10.1016/j.foodchem.2006.06.055.

Park, K. J., Bin, A., Pedro, F., Brod, R., Hae, T., \& Brandini, K. (2002). Osmotic dehydration kinetics of pear D' anjou (Pyrus communis L.). Journal of Food Engineering, 52(3), 293-298. http://dx.doi. org/10.1016/S0260-8774(01)00118-2.

Pereira, L. M., Ferrari, C. C., Mastrantonio, D. S., Rodrigues, A. C. C., \& Hubinger, M. D. (2006). Kinetic aspects, texture, and colour evaluation of some tropical fruits during osmotic dehydration. Drying Technology, 24(4), 475-484. http://dx.doi.org/10.1080/07373930600611968.

Rahman, M. S., Al-Zakwani, I., \& Guizani, N. (2005). Pore formation in apple during air-drying as a function of temperature: porosity and pore-size distribution. Journal of the Science of Food and Agriculture, 85(6), 979-989. http://dx.doi.org/10.1002/jsfa.2056.

Rózek, A., Achaerandio, I., Güell, C., López, F., \& Ferrando, M. (2009). Grape phenolic impregnation by osmotic treatment: Influence of osmotic agent on mass transfer and product characteristics. Journal of Food Engineering, 94(1), 59-68. http://dx.doi.org/10.1016/j. jfoodeng.2009.02.030.

Rózek, A., García-Pérez, J. V., López, F., Güell, C., \& Ferrando, M. (2010). Infusion of grape phenolics into fruits and vegetables by osmotic treatment: phenolic stability during air drying. Journal of Food Engineering, 99(2), 142-150. http://dx.doi.org/10.1016/j. jfoodeng.2010.02.011.

Şahin, U., \& Öztürk, H. K. (2016). Effects of pulsed vacuum osmotic dehydration (PVOD) on drying kinetics of figs (Ficus carica L). Innovative Food Science \& Emerging Technologies, 36, 104-111. http://dx.doi.org/10.1016/j.ifset.2016.06.003.

Santacruz-Vazquez, C., Santacruz-Vazquez, V., Jaramillo-Flores, M. E., Chanona-Perez, J., Welti-Chanes, J., \& Gutiérrez-Lopez, G. F. (2008). Application of osmotic dehydration processes to produce apple slices enriched with $\beta$-Carotene. Drying Technology, 26(10), 1265-1271. http://dx.doi.org/10.1080/07373930802307266.

Saputra, D. (2001). Osmotic dehydration of pineapple. Drying Technology, 19(2), 415-425. http://dx.doi.org/10.1081/DRT-100102914.

Shi, J., \& Le Maguer, M. (2002). Osmotic dehydration of food: mass transfer and modelling aspects. Food Reviews International, 18(4), 305-335. http://dx.doi.org/10.1081/FRI-120016208.

Simpson, R., Ramírez, C., Nuñez, H., Jaques, A., \& Almonacid, S. (2017). Understanding the success of Page's model and related empirical equations in fitting experimental data of diffusion phenomena in food matrices. Trends in Food Science \& Technology, 62, 194-201. http://dx.doi.org/10.1016/j.tifs.2017.01.003.

Teles, U., Fernandes, F. A. N., Rodrigues, S., Lima, A. S., Maia, G. A., \& Figueiredo, R. W. (2006). Optimization of osmotic dehydration of melons followed by air-drying. International Journal of Food Science \& Technology, 41(6), 674-680. http://dx.doi.org/10.1111/j.13652621.2005.01134.x.

Wang, H., Cao, G., \& Prior, R. (1997). Oxygen radical absorbing capacity of anthocyanins. Journal of Agricultural and Food Chemistry, 45(2), 304-309. http://dx.doi.org/10.1021/jf960421t.

Wang, S. Y., \& Lin, H. S. (2000). Antioxidant activity in fruits and leaves of blackberry, raspberry, and strawberry varies with cultivar and developmental stage. Journal of Agricultural and Food Chemistry, 48(2), 140-146. http://dx.doi.org/10.1021/jf9908345. PMid:10691606.

Wu, X., Cao, G., \& Prior, R. L. (2002). Absorption and metabolism of anthocyanins in elderly women after consumption of elderberry or blueberry. The Journal of Nutrition, 132(7), 1865-1871. http:// dx.doi.org/10.1093/jn/132.7.1865. PMid:12097661.

Zapata, J. E., Ciro, G. L., \& Marulanda, P. (2016). Optimization of pulsed vacuum osmotic dehydration of the cape gooseberry (Physalis peruviana L.) using the response surface methodology. Agronomia Colombiana, 34(2), 228-238. http://dx.doi.org/10.15446/agron. colomb.v34n2.54920.

Zhang, Z., Kou, X., Fugal, K., \& McLaughlin, J. (2004). Comparison of HPLC methods for determination of anthocyanins and anthocyanidins in bilberry extracts. Journal of Agricultural and Food Chemistry, 52(4), 688-691. http://dx.doi.org/10.1021/jf034596w. PMid:14969517. 